\title{
Antiproliferative Activity of Non-Calcemic Vitamin D Analogs on Human Melanoma Lines in Relation to VDR and PDIA3 Receptors
}

\author{
Tomasz Wasiewicz ${ }^{1}$, Anna Piotrowska ${ }^{1}$, Justyna Wierzbicka ${ }^{1}$ (D), Andrzej T. Slominski ${ }^{2,3,4}$ ([) \\ and Michal A. Zmijewski ${ }^{1, *}$ \\ 1 Department of Histology, Medical University of Gdansk, 80-210 Gdansk, Poland; \\ tomwasxp@poczta.onet.pl (T.W.); annapiotrowska@gumed.edu.pl (A.P.); \\ justyna.wierzbicka@gumed.edu.pl (J.W.) \\ 2 Department of Dermatology, University of Alabama, Birmingham, AL 35294, USA; aslominski@uabmc.edu \\ 3 Comprehensive Cancer Center, Cancer Chemoprevention Program, University of Alabama, \\ Birmingham, AL 35294, USA \\ 4 VA Medical Center, Birmingham, AL 35294, USA \\ * Correspondence: mzmijewski@gumed.edu.pl; Tel.: +48-58-349-1455; Fax: +48-58-349-1419
}

Received: 2 August 2018; Accepted: 24 August 2018; Published: 31 August 2018

\begin{abstract}
Vitamin D is a precursor for secosteroidal hormones, which demonstrate pleiotropic biological activities, including the regulation of growth and the differentiation of normal and malignant cells. Our previous studies have indicated that the inhibition of melanoma proliferation by a short side-chain, low calcemic analog of vitamin $\mathrm{D}-21(\mathrm{OH}) \mathrm{pD}$ is not fully dependent on the expression of vitamin D receptor (VDR). We have examined the effects of classic vitamin $\mathrm{D}$ metabolites, $1,25(\mathrm{OH})_{2} \mathrm{D}_{3}$ and $25(\mathrm{OH}) \mathrm{D}_{3}$, and two low calcemic vitamin $\mathrm{D}$ analogs, $(21(\mathrm{OH}) \mathrm{pD}$ and calcipotriol), on proliferation, mRNA expression and vitamin D receptor (VDR) translocation in three human melanoma cell lines: WM98, A375 and SK-MEL-188b (subline b of SK-MEL-188, which lost responsiveness to $1,25(\mathrm{OH})_{2} \mathrm{D}_{3}$ and became $\mathrm{VDR}^{-/-} \mathrm{CYP}^{-7 B 1^{-/}}{ }^{-}$). All tested compounds efficiently inhibited the proliferation of WM98 and A375 melanoma cells except SK-MEL-188b, in which only the short side-chain vitamin $\mathrm{D}$ analog-21(OH)pD was effective. Overall, $21(\mathrm{OH}) \mathrm{pD}$ was the most potent compound in all three melanoma cell lines in the study. The lack of responsiveness of SK-MEL-188b to $1,25(\mathrm{OH})_{2} \mathrm{D}_{3}, 25(\mathrm{OH}) \mathrm{D}_{3}$ and calcipotriol is explained by a lack of characteristic transcripts for the $V D R$, its splicing variants as well as for vitamin D-activating enzyme CYP27B1. On the other hand, the expression of $V D R$ and its splicing variants and other vitamin D related genes $(R X R$, PDIA3, CYP3A4, CYP2R1, CYP27B1, CYP24A1 and CYP11A1) was detected in WM98 and A375 melanomas with the transcript levels being modulated by vitamin $\mathrm{D}$ analogs. The expression of $V D R$ isoforms in WM98 cells was stimulated strongly by calcipotriol. The antiproliferative activities of $21(\mathrm{OH}) \mathrm{pD}$ appear not to require VDR translocation to the nucleus, which explains the high efficacy of this noncalcemic pregnacalciferol analog in SK-MEL-188b melanoma, that is, $\mathrm{VDR}^{-/-}$. Therefore, we propose that $21(\mathrm{OH}) \mathrm{pD}$ is a good candidate for melanoma therapy, although the mechanism of its action remains to be defined.
\end{abstract}

Keywords: vitamin D; $1,25(\mathrm{OH})_{2} \mathrm{D}_{3}$; calcipotriol; $21(\mathrm{OH}) \mathrm{pD}$; vitamin D analogs; melanoma; human melanoma cell lines; VDR translocation; anti-melanoma activity

\section{Introduction}

Vitamin D is a naturally occurring hormone precursor, which after activation serves as a pleiotropic regulator of homeostasis on cellular and whole organism levels [1,2]. It is produced in 
the skin which is subjected to the ultraviolet B (UVB) fraction of sunlight or could be acquired from nutritional sources and supplementation. UVB exposure results in the conversion of epidermal 7-dehydrocholesterol (7DHC) into pre-vitamin $\mathrm{D}_{3}$, which undergoes subsequent isomerization to vitamin $\mathrm{D}_{3}$ [2-5]. Vitamin $\mathrm{D}_{3}$ has to be hydroxylated in order to implement its biological activities. The first step takes place in the liver, where vitamin $\mathrm{D}_{3}$ is converted to $25(\mathrm{OH}) \mathrm{D}_{3}$ (25-hydroxyvitamin $\mathrm{D}_{3}$, calcifediol) by CYP2R1, CYP27A1 or CYP3A4 (CYP3A4 belongs to cytochrome P450 superfamily and is involved in drug metabolism, but also has a capacity for vitamin D hydroxylation), and $25(\mathrm{OH}) \mathrm{D}_{3}$ is subsequently hydroxylated by $1 \alpha$-hydroxylase (CYP27B1) in the kidney. In addition, $1,25(\mathrm{OH})_{2} \mathrm{D}_{3}$ can be generated locally in many cell types (keratinocytes, dendritic cells, melanocytes, lymphocytes and cancer cells) expressing appropriate enzymatic machinery [6,7]. The level of $1,25(\mathrm{OH})_{2} \mathrm{D}_{3}$ and its metabolites in circulation are tightly regulated through a negative feedback loop by 24-hydroxylase (CYP24A1), which metabolizes calcitriol into water-soluble and inactive calcitroic acid [8]. The catalytically inactive splicing variant of CYP24A1 (CYP24SV) may serve as dominant negative regulator of vitamin $\mathrm{D}_{3}$ catabolism and possibly contribute to the extracellular accumulation of $1,25(\mathrm{OH}) 2 \mathrm{D}_{3}$ [9]. Most recently, it was discovered that CYP11A1, the rate limiting enzyme of steroidogenesis, also metabolizes 7DHC, vitamin $\mathrm{D}_{3}$ and lumisterol to their corresponding hydroxyderivatives with full and short side-chains [10-15].

According to the genomic pathway, active forms of vitamin $\mathrm{D}_{3}$ exert their biological activities through interactions with the VDR, which is expressed by a majority of cells in the body [16,17]. Activated VDR forms a heterodimer with retinoid X receptor (RXR), and this complex is translocated to the nucleus where it binds to the VDREs (vitamin D response elements) and activates the expression of hundreds of human genes $[17,18]$. The activity of this complex is also regulated by the recruitment of co-activators or co-repressors to modulate the expression of selected genes, including those participating in the inhibition of cell cycle progression and the stimulation of differentiation and apoptosis [19-22].

In addition to the well-characterized vitamin $\mathrm{D}_{3}$ genomic actions, its analogs may also exert a rapid, non-genomic response (RR: rapid response) [23-25]. There is growing evidence that the co-localization of VDR $[26,27]$ with caveolae of plasma membrane, as well as the binding of vitamin D to PDIA3 (Protein disulfide-isomerase A3), is responsible for the alternative (non-genomic) action of vitamin $\mathrm{D}_{3}$ and its analogs $[23,28]$.

According to epidemiological studies, the incidence of human malignant melanoma has been increasing steadily since the 1970s [29-32]. Early detection of melanoma results in a good prognosis for patients; however, the survival rate and therapeutic procedures for advanced or metastatic melanomas are very limited. Ultraviolet radiation, in addition to being fully carcinogenic and a main cause of melanoma [32-34], is also the most important factor promoting the formation of vitamin $\mathrm{D}_{3}$. The anti-melanoma activity of vitamin D derivatives have been reported previously [35-40]. In addition, the presence of specific polymorphisms of $V D R$ [41-43] or a decreased expression of $V D R, C Y P 27 B 1, C Y P 24 A 1$ and defects in vitamin D signaling are linked to more advanced stages of melanoma or poorer prognosis [44-48]. Furthermore, proper supplementation with vitamin D is believed to be an important factor in cancer prevention [47,49-51].

Active forms of vitamin $\mathrm{D}_{3}$ show antiproliferative properties against several types of cancer, including colorectal cancer [52], breast cancer [53], prostate cancer [54] and melanoma [39,40,55-59]. Furthermore, the use of $1,25(\mathrm{OH})_{2} \mathrm{D}_{3}$ as an anticancer drug in very high concentrations (above 50,000 units/day) is currently under clinical investigation; however, it has to be acknowledged that it could potentially cause hypercalcemia $[40,50,60]$. Since vitamin $\mathrm{D}_{3}$ analogs with modified or shortened side-chains were shown to have low or no effect on calcium levels [59,61-63], they are potentially better alternatives for calcitriol. So far, more than 3000 vitamin $\mathrm{D}_{3}$ analogs have been synthesized, and their biological activity is still intensively investigated as a single agent or in combination with other cytostatics [40,64-66]. In this study, we have investigated the response of three human melanoma cell lines against four vitamin $\mathrm{D}_{3}$ analogs. We have analyzed the antiproliferative potential of analogs 
(Figure 1) and found that $21(\mathrm{OH}) \mathrm{pD}$ inhibits melanoma growth through a mechanism independent from VDR or PDIA3.

A

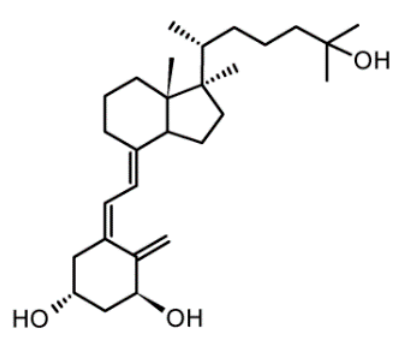

B

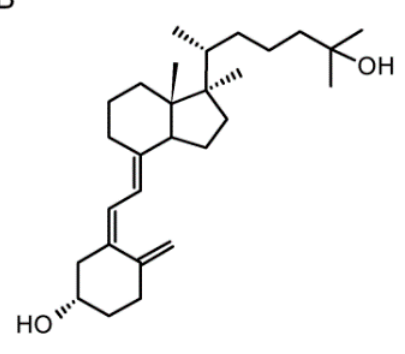

C

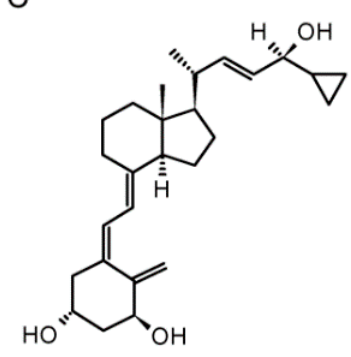

$\mathrm{D}$<smiles>C=C1CC[C@@H](O)C/C1=C\C=C1/CCCC2C1CC[C@]2(C)C(=O)CO</smiles>

Figure 1. Chemical structure of vitamin $\mathrm{D}_{3}$ analogs: $1,25(\mathrm{OH})_{2} \mathrm{D}_{3}(\mathbf{A}), 25(\mathrm{OH}) \mathrm{D}_{3}(\mathbf{B})$, calcipotriol (C) and $21(\mathrm{OH}) \mathrm{pD}(\mathrm{D})$.

\section{Results}

\subsection{New Vitamin $D_{3}$ Analogs Effectively Inhibit A375 Cell Proliferation}

Our previous studies on human melanomas SK-MEL-188 [10,39,57,59,62,67-69], A375 [55], and WM98 $[39,68]$ demonstrated the sensitivity of melanoma cells to vitamin $\mathrm{D}_{3}$ analogs with short and full side-chains. The efficacy of compounds was attenuated by melanogenesis, which was associated with the downregulation of VDR expression $[56,68]$. However, it was also shown that the antiproliferative activity of short side-chain analogs of vitamin $\mathrm{D}_{3}$, such as $21(\mathrm{OH}) \mathrm{pD}$, were not fully dependent on VDR expression in rodent melanomas [56], consistent with the poor docking score on the ligand binding domain of the VDR and the poor translocation of VDR to the nucleus [69].

To better understand the effect of VDR expression on the differential action of vitamin $\mathrm{D}_{3}$ analogs, we used three human melanoma lines, A375 and WM98 and a subline b of SKMEL-188 which lost responsiveness to vitamin D during in vitro passaging [55], and detected the VDR expression and sensitivity to selected vitamin $\mathrm{D}$ analogs $\left(1,25(\mathrm{OH})_{2} \mathrm{D}_{3}, 25(\mathrm{OH}) \mathrm{D}_{3}, 21(\mathrm{OH}) \mathrm{pD}\right.$ and calcipotriol). As expected, these compounds [40,65] effectively inhibited the proliferation of A375 and WM98 melanomas expressing VDR receptor. $\mathrm{IC}_{50}$ values ranged from $\mathrm{pM}$ to $\mu \mathrm{M}$, and the effects on cell proliferation were strongly dependent on the melanoma cell line and the nature of the compound. Interestingly, non-pigmented SK-MEL-188b was found to be resistant to vitamin $\mathrm{D}_{3}$ analogs with a full-length side-chain $\left(1,25(\mathrm{OH})_{2} \mathrm{D}_{3}, 25(\mathrm{OH}) \mathrm{D}_{3}\right.$ and calcipotriol) and sensitive to short side-chained $21(\mathrm{OH}) \mathrm{pD}$ (Figure 2). Overall, $21(\mathrm{OH}) \mathrm{pD}$ was found to be the most potent inhibitor of growth in tested melanoma cell lines. 
SK-MEL-188b
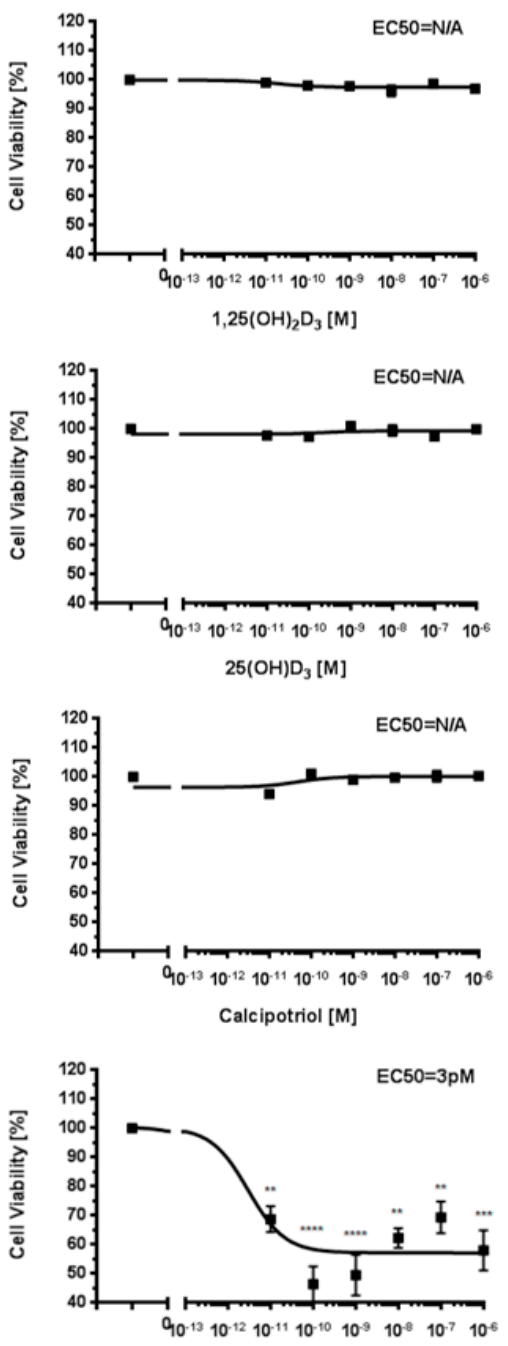

$21(\mathrm{OH}) \mathrm{pD}[\mathrm{M}]$
A375
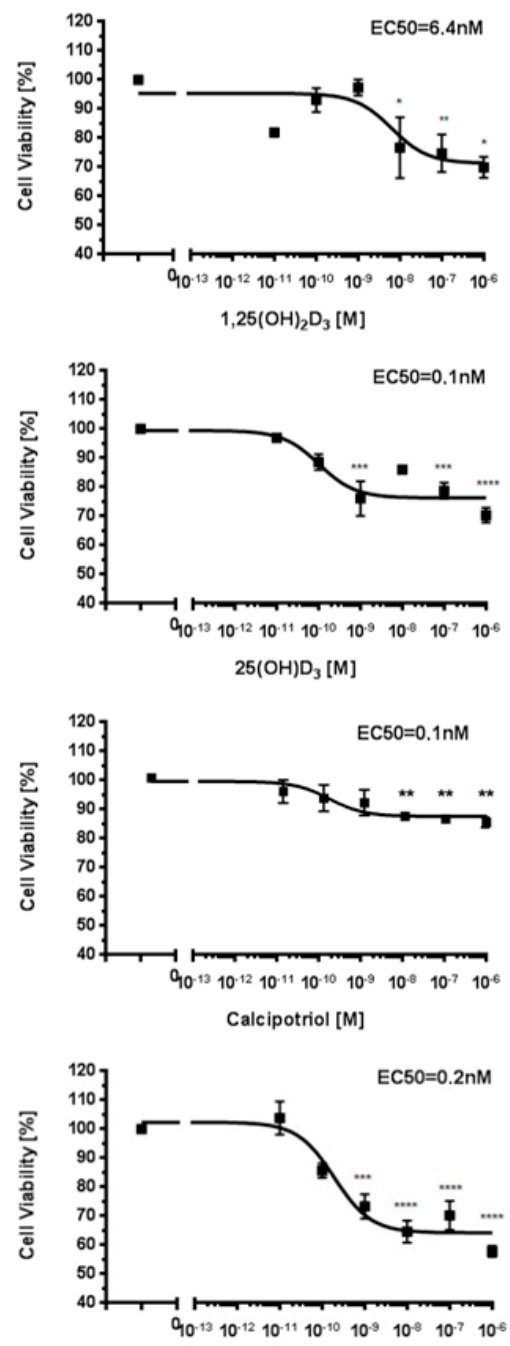

$21(\mathrm{OH}) \mathrm{pD}[\mathrm{M}]$
WM98
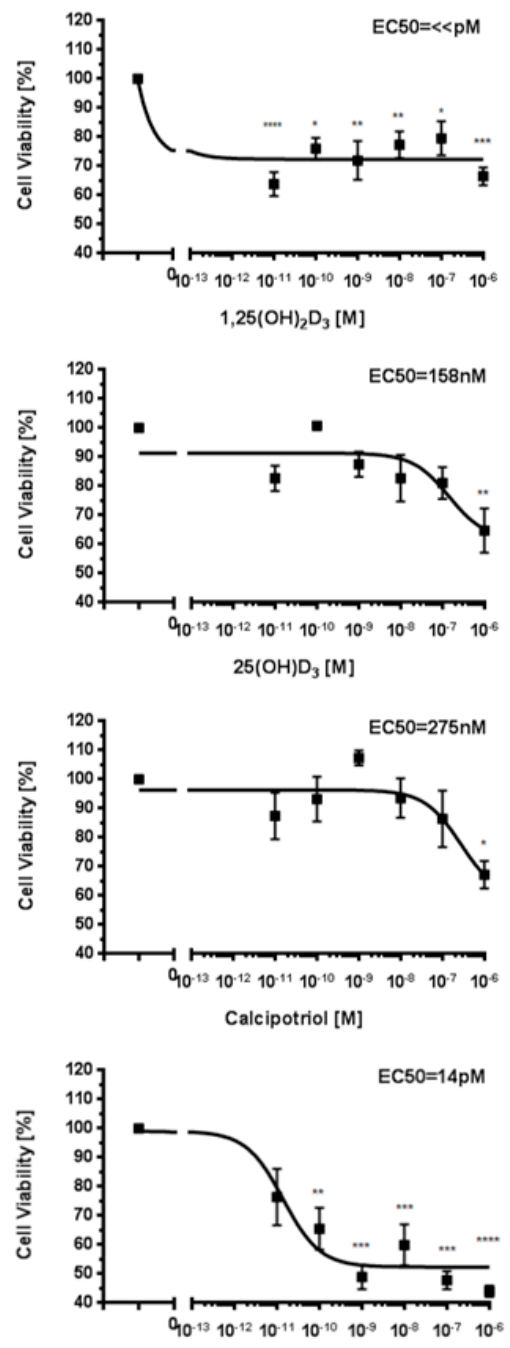

$21(\mathrm{OH}) \mathrm{pD}[\mathrm{M}]$

Figure 2. Effects of $1,25(\mathrm{OH})_{2} \mathrm{D}_{3}, 25(\mathrm{OH}) \mathrm{D}_{3}$, calcipotriol and $21(\mathrm{OH}) \mathrm{pD}$ on growth of human SK-MEL-188b, A375 and WM98 melanoma cells. Cells were seeded into 96-well plates and incubated in a medium supplemented with serial dilution of vitamin D analogs from $0.01 \mathrm{nM}$ to $1000 \mathrm{nM}$ concentration (as described in Material and Methods). The statistical significance of results has been analyzed using one-way ANOVA (GraphPad Software, San Diego, CA, USA) and data are presented as means \pm SEM for at least three independent measurements. The cutoff point of significance was

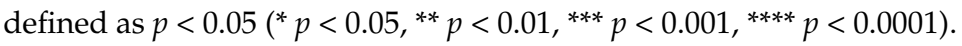

\subsection{The Effect of Vitamin $D_{3}$ Compounds on the Expression of Genes Related to Vitamin $D_{3}$ Action or Metabolism}

First, we investigated the expression of vitamin $\mathrm{D}_{3}$-related genes in untreated melanoma cells. As shown in Figure 3, PCR fragments characteristic for VDR, CYP27A1 and CYP27B1 mRNAs were below the level of detectability in SK-MEL-188b melanoma, which did not respond to vitamin D. Only the mRNA of PDIA3 was detected in this line. On the other hand, in A375 and WM98, cell lines corresponding to transcripts for all tested genes were detected.

Next, we tested the effects of vitamin $\mathrm{D}_{3}$ analogues on the relative mRNA levels of vitamin $\mathrm{D}_{3}$-related genes in responsive melanoma cell lines (A375 and WM98). The treatment of WM98 melanoma with full length side-chain vitamin $\mathrm{D}_{3}$ analogs $\left(1,25(\mathrm{OH})_{2} \mathrm{D}_{3}, 25(\mathrm{OH}) \mathrm{D}_{3}\right.$ and calcipotriol) is presented in Figure 4 . Only $1,25(\mathrm{OH})_{2} \mathrm{D}_{3}$ stimulated the expression of $V D R$ Co-receptor $R X R$ 
and of CYP27A1 (Figure 4B). All three analogs, however, stimulated the expression of CYP3A4, $C Y P 2 R 1, C Y P 24 A 1$ and its splicing variant CYP24A1sv. Interestingly, the strongest effect (approximately a 6-fold induction) on CYP2R1 mRNA level was observed in cells treated with calcipotriol (Figure 4C). Furthermore, the level of CYP27B1 mRNA was not affected by tested secosteroids (Figure 4G), while the expression of PDIA3 was stimulated only by $25(\mathrm{OH}) \mathrm{D}_{3}$ (Figure $4 \mathrm{E}$ ).

The treatment of $\mathrm{A} 375$ melanoma with four vitamin $\mathrm{D}_{3}$ analogs $\left(1,25(\mathrm{OH})_{2} \mathrm{D}_{3}\right.$, calcipotriol and $21(\mathrm{OH}) \mathrm{pD}$ ) decreased the expression of $V D R, R X R, P D I A 3, C Y P 2 R 1$ genes (Figure 5). Interestingly, the strongest decrease in the mRNA levels of CYP3A4 and CYP2R1 was observed in A375 melanoma cells treated with $21(\mathrm{OH}) \mathrm{pD}$. The induction of $C Y P 24 A 1$ gene was hundreds of times folds higher in cells treated with $1,25(\mathrm{OH})_{2} \mathrm{D}_{3}$ and calcipotriol when compared to $21(\mathrm{OH}) \mathrm{pD}$, showing minimal effect. Finally, the mRNA level of CYP27B1 was not affected by vitamin D analogues and CYP11A1 was elevated in A375 melanoma cells only after treatment with calcipotriol.

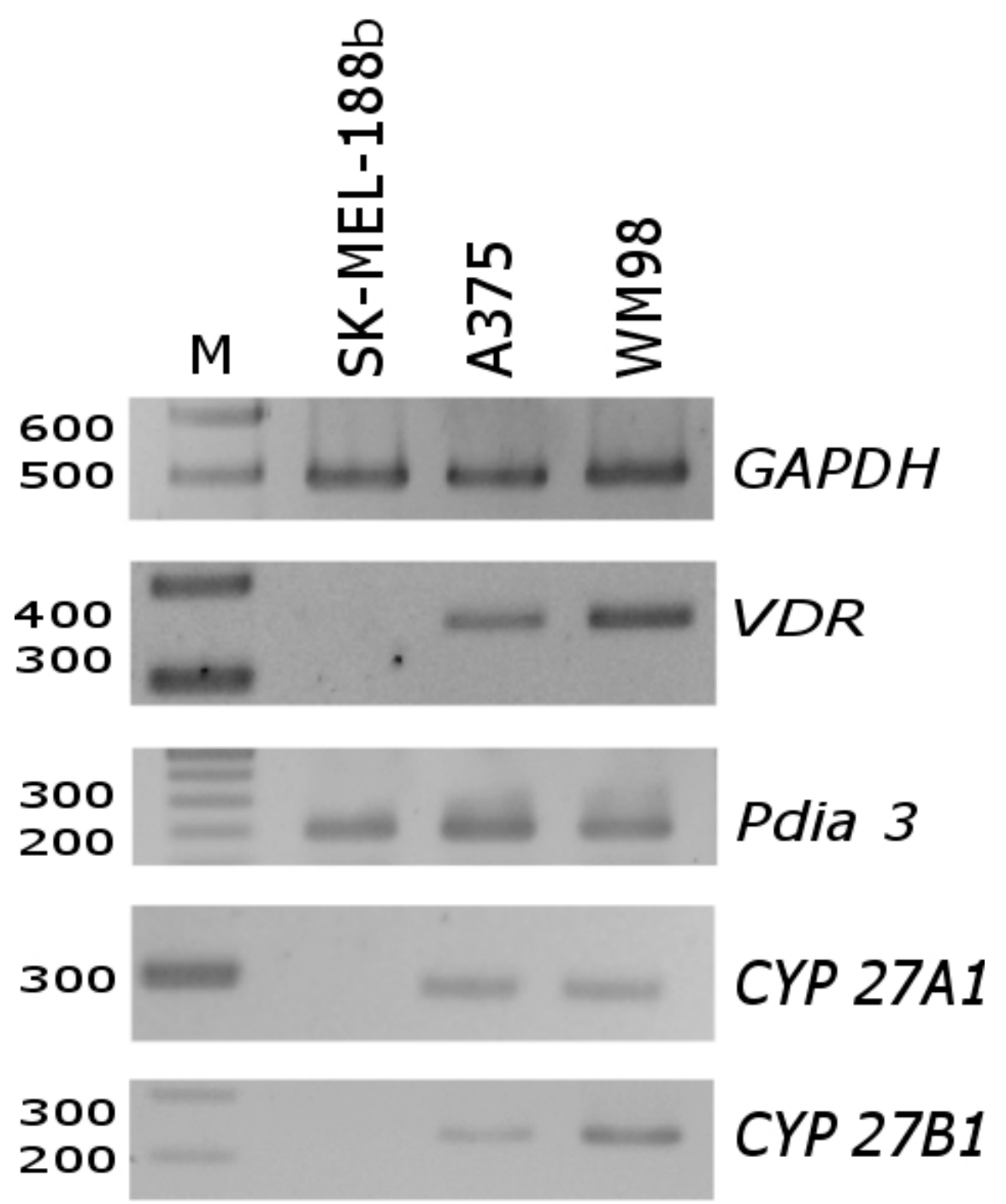

Figure 3. Differences in mRNA level of VDR, PDIA3, CYP27A1 and CYP27B1 genes in SK-MEL-188b cells in comparison with A375 and WM98 cells. Glyceraldehyde 3-phosphate dehydrogenase (GAPDH) was used as a reporter gene to normalize all samples. See Table S1 for primer sequences and the predicted length of PCR fragments. 
A

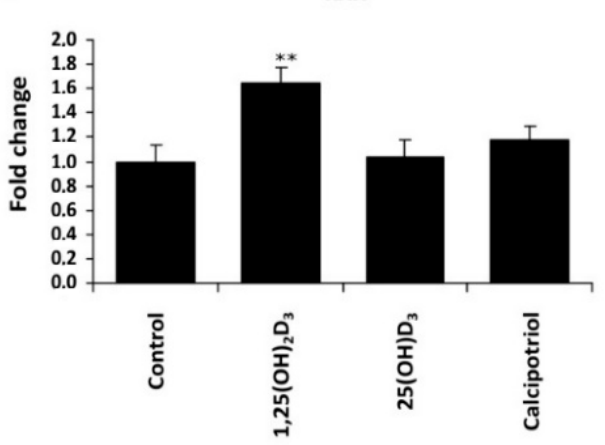

B

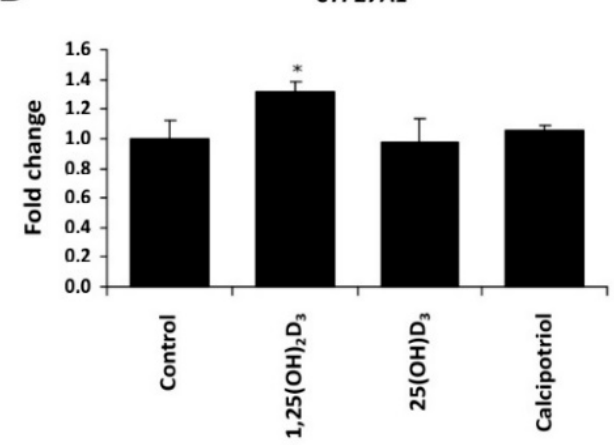

C

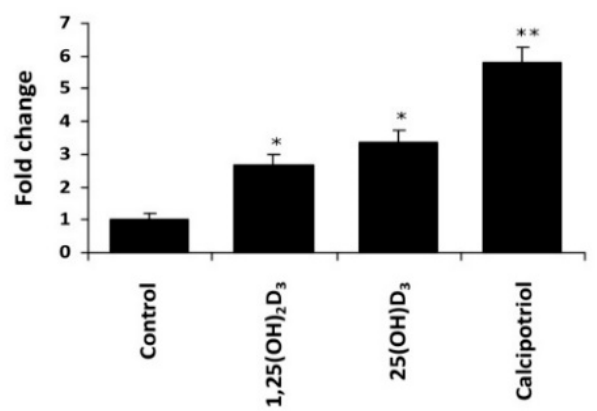

D

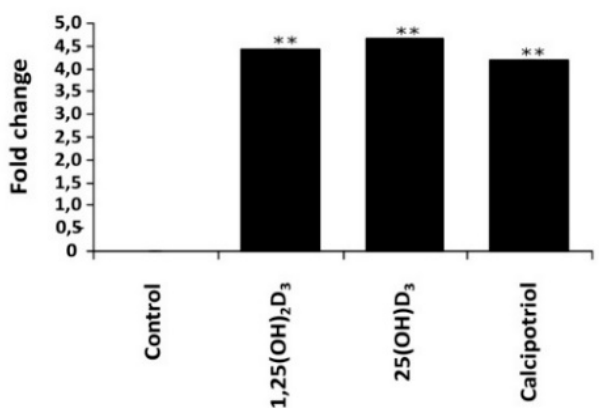

E

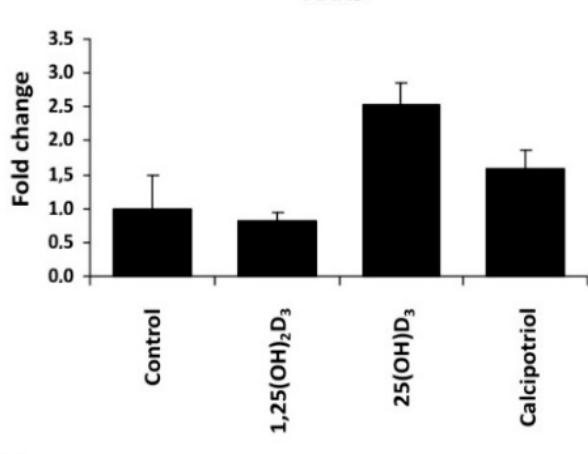

$\mathrm{F}$

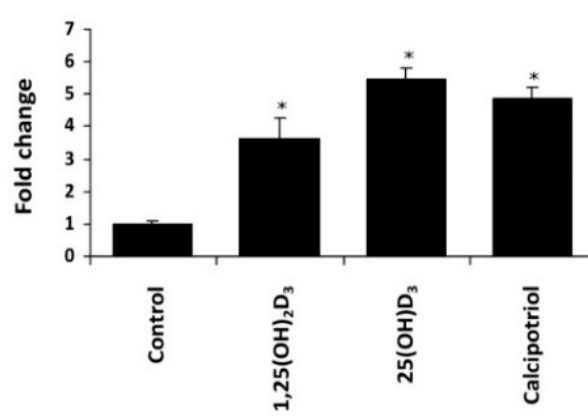

G

CYP27B1

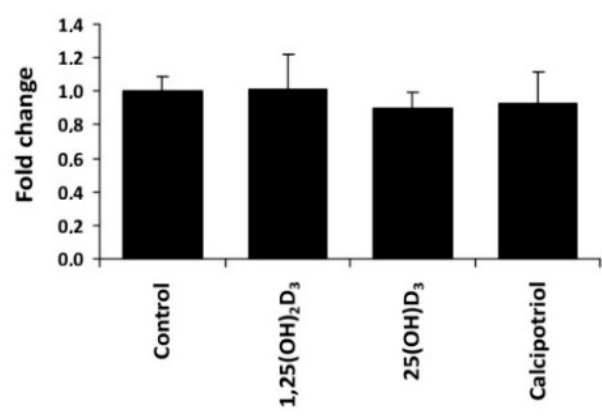

$\mathrm{H}$

CYP24SV

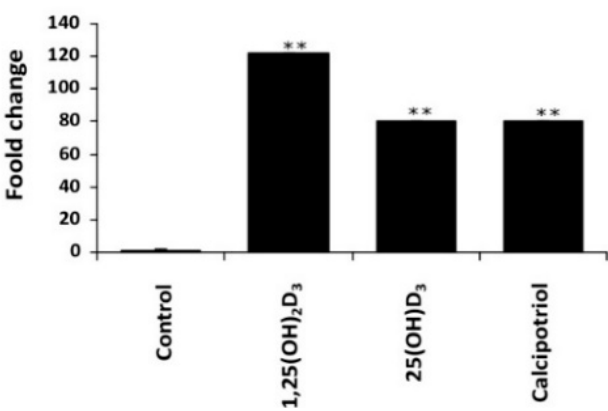

Figure 4. Vitamin $\mathrm{D}$ analogs treatment modulate the expression of (A) retinoid $\mathrm{X}$ receptor $(R X R),($ E) disulfide isomerase (PDIA3), 25-hydoxylases ((B) CYP27A1, (C) CYP2R1 or (F) CYP3A4, (G) $1 \alpha$-hydroxylase (CYP27B1)) and 24-hydroxylases ((D) CYP24A1 or (H) CYP24SV) in WM98

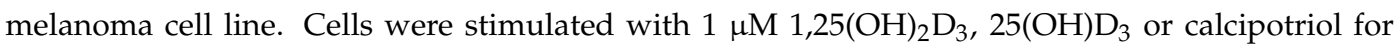
$24 \mathrm{~h}$. Quantitative PCR analyses were performed as described in Materials and Methods. Statistical significance was estimated using $t$-test and data are presented as means $\pm \mathrm{SD}(n=3)$. The cutoff point for significance is defined as $p<0.05\left({ }^{*} p<0.05,{ }^{* *} p<0.01\right)$. 
A

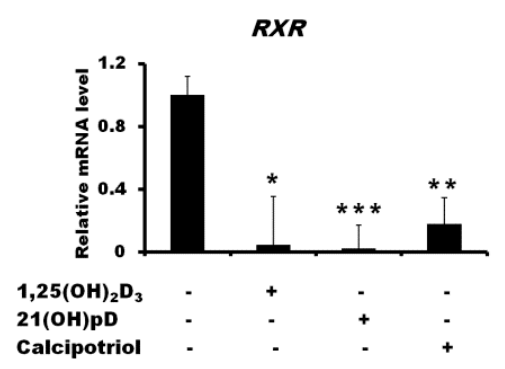

D

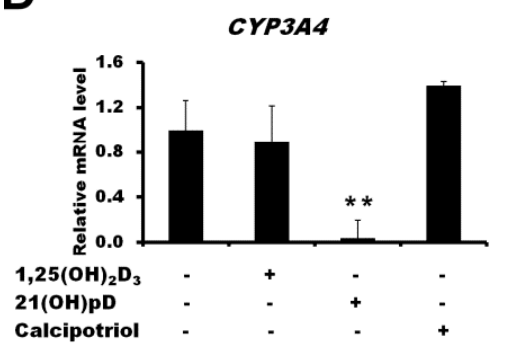

G

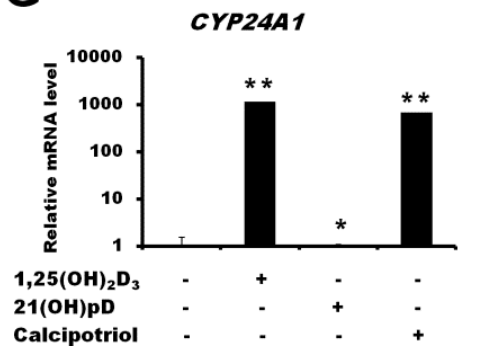

B

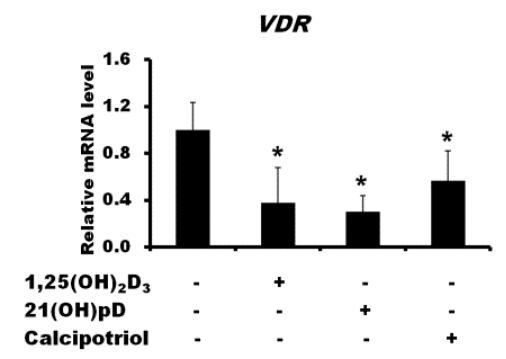

E

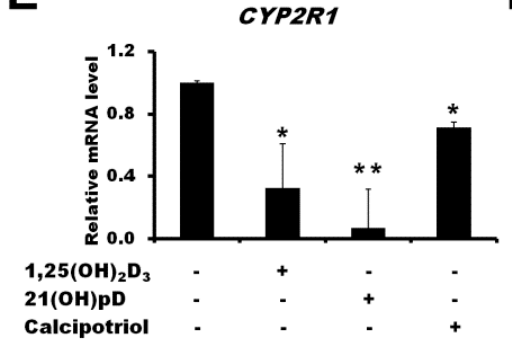

$\mathbf{F}$

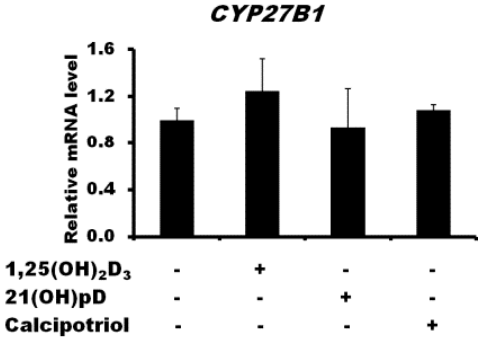

Figure 5. Effects of vitamin $\mathrm{D}$ compounds $\left(1,25(\mathrm{OH})_{2} \mathrm{D}_{3}, 21(\mathrm{OH}) \mathrm{pD}\right.$ or calcipotriol) on $R X R(\mathrm{~A})$, VDR (B), PDIA3 (C), CYP3A4 (D), CYP2R1 (E), CYP27B1 (F), CYP24A1 (G) and CYP11A1 (H) genes expression in A375 melanoma cells. A375 melanoma cells were incubated with $100 \mathrm{nM}$ of $1,25(\mathrm{OH})_{2} \mathrm{D}_{3}$, $21(\mathrm{OH}) \mathrm{pD}$ or calcipotriol for $24 \mathrm{~h}$. mRNA levels were measured by qPCR. Data are shown as means \pm S.D of three independent experiments carried out in duplicate. The cutoff point for significance is defined as $p<0.05\left({ }^{*} p<0.05,{ }^{* *} p<0.01,{ }^{* *} p<0.001\right)$.

It is well established that the antiproliferative effects of vitamin $\mathrm{D}_{3}$ analogs strongly depend on the expression of vitamin D receptor VDR $[40,47,65]$. As shown in Figure 3, the melanoma cell lines used in the study differ in their basal level of VDR expression, and the transcript is absent in SK-MEL-188b, which is not responsive to vitamin D. Theoretically, an alternative splicing of $V D R$ pre-mRNA may results in the production of at least five alternative transcripts (Figure 6A); thus, the unique set of primers was designed in order to detect specific variants of VDR mRNA (Table S1). Detection of specific variants of $V D R$ was confirmed by sequencing of PCR fragments previously separated on agarose gel (Figure 6B). WM98 and A375 melanoma cell lines express all four PCR fragments (Pr 1, $\operatorname{Pr} 2, \operatorname{Pr} 4$ and $\operatorname{Pr} 5$ ) corresponding to $V D R$ splicing variant c (Figure 6A). In the WM98 melanoma, the cell line presence of an mRNA characteristic for isoforms a $(\operatorname{Pr} 3)$ and $b(\operatorname{Pr} 4$, upper band) was also detected. Interestingly, in SK-MEL-188b melanoma cells, only one fragment of mRNA corresponding to the alternative promoter region of $V D R$ (isoform c) was detected. Finally, the effects of two vitamin $\mathrm{D}_{3}$ analogs $25(\mathrm{OH}) \mathrm{D}_{3}$ and calcipotriol on the alternative splicing of $V D R$ pre-mRNA was tested in WM98 cell line (Figure $6 \mathrm{C}$ ). It was show that treatment with calcipotriol, but not $25(\mathrm{OH}) \mathrm{D}_{3}$, resulted in at least 7-fold elevation of mRNA levels corresponding to all fragments of the VDR tested (fragments detected by a set of primers: $\operatorname{Pr} 1$ to $\operatorname{Pr} 5)$. 
A

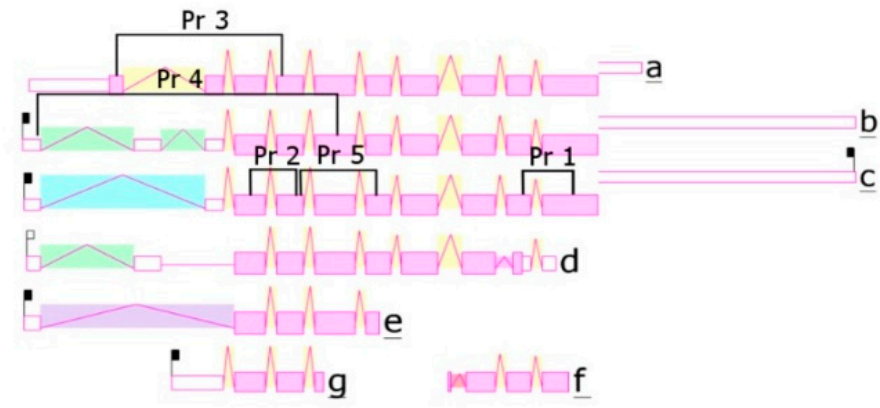

6

4

218

B

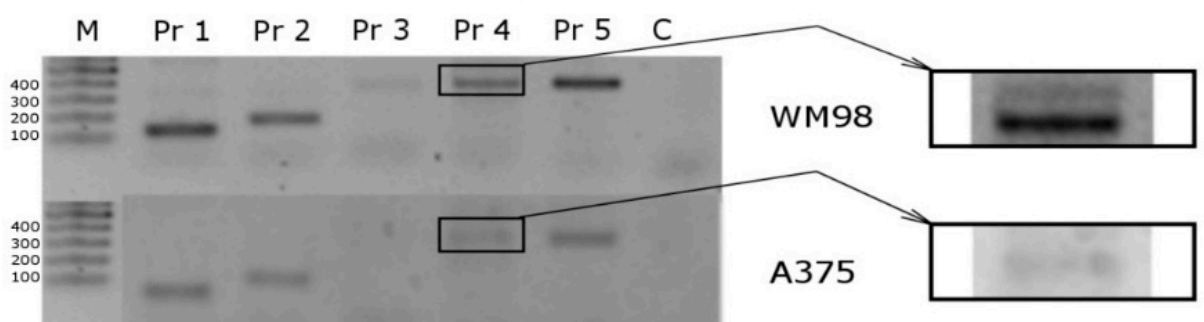

SK-MEL-188

C
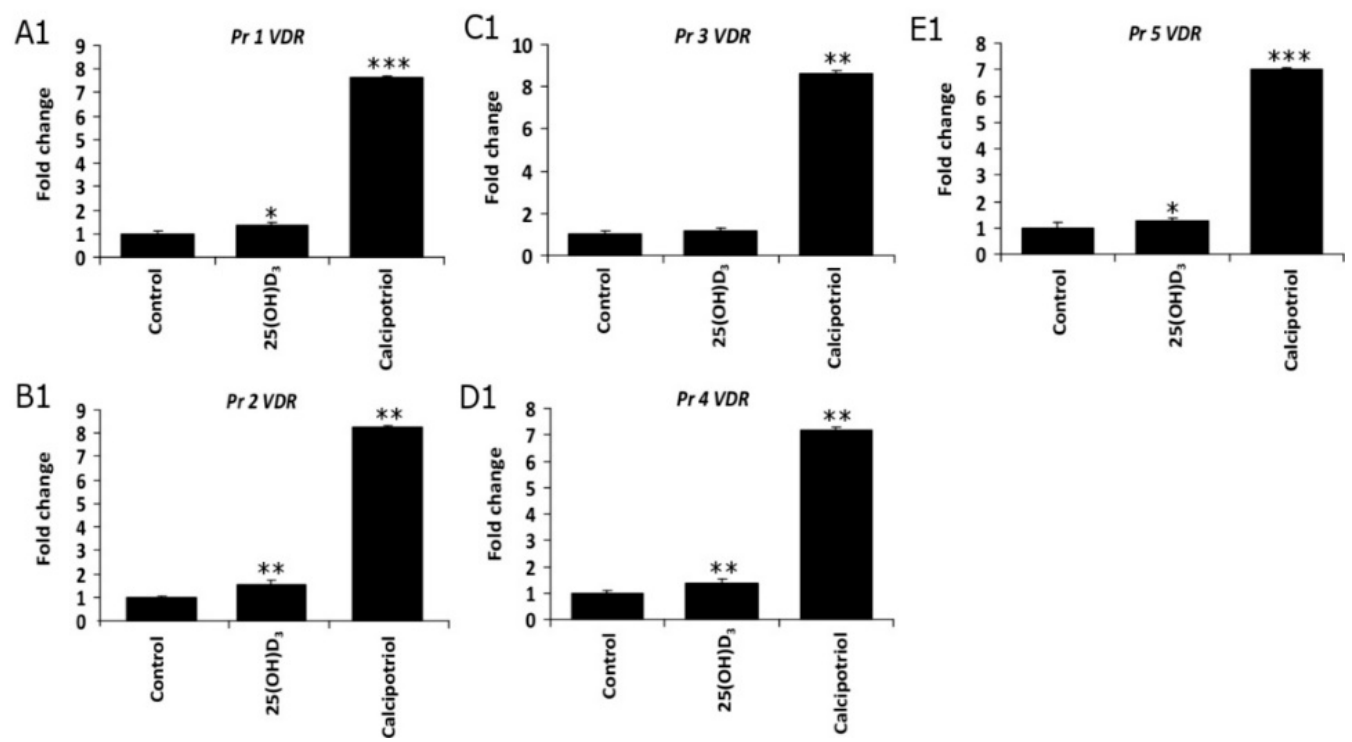

Figure 6. (A) Five different PCR primers sets were designed ( $\operatorname{Pr} 1-\operatorname{Pr} 5)$ in order to detect the expression of VDR splicing variants in WM98, A375 and SK-MEL-188b cell lines. The most common isoforms are $\mathrm{a} b$ and $\mathrm{c}$ and the rarely identified isoforms are $\mathrm{d}, \mathrm{e}, \mathrm{f}$ and $\mathrm{g}$. The positions of sets of primers designed to differentiate VDR isoforms is also shown. Product $1(\operatorname{Pr} 1)$ of 132 b.p. is characteristic for isoforms a, b, c and f; Product 2 (Pr 2) of 180 b.p. is universal for all isoforms accept f; Product 3 (Pr 3) of 386 b.p. is unique for isoform a; Product 4 (Pr 4), depending on length of the PCR fragment, indicates isoform " $b$ " 532 b.p. or "c" 410 b.p.; Product 5 (Pr 5) of 384 b.p. is characteristic for isoforms $\mathrm{a}, \mathrm{b}, \mathrm{c}, \mathrm{d}$ and $\mathrm{e}$, but not $\mathrm{g}$ and $\mathrm{f}$ (diagram of VDR splicing variants taken from AceView https:/ / www.ncbi.nlm.nih.gov/IEB/Research/Acembly/). (B) Semiquntitative PCR was used to differentiate the $V D R$ isoforms (see Material and Methods for details); molecular weight marker (M) as described in. (C) Effects of vitamin D analogs on the expression of $V D R$ isoforms were analyzed in WM98 melanoma cells. Melanoma cells were treated with $25(\mathrm{OH}) \mathrm{D}_{3}$ or calcipotriol at $1 \mu \mathrm{M}$ concentration for $24 \mathrm{~h}$. Statistical significance was estimated using $t$-test and data are presented as means $\pm \mathrm{SD}(n=3)$. The cutoff point for significance is defined as $p<0.05\left({ }^{*} p<0.05,{ }^{* *} p<0.01\right.$, $* * * p 0.001)$. 


\subsection{Translocation of Vitamin D Receptor by Secosteroids}

The ligand-induced translocation of VDR receptor into the nucleus was studied using A375 cells stably transduced with pLenti-CMV-VDR-EGFP lentiviral construct [70]. $1,25(\mathrm{OH})_{2} \mathrm{D}_{3}$ or calcipotriol induced a dose-dependent and efficient translocation of VDR-GFP fusion protein into the nucleus (Figure 7). A lack of VDR-GFP translocation to the nucleus was observed in cells treated with $21(\mathrm{OH}) \mathrm{pD}$.

A

\begin{tabular}{|c|c|c|}
\hline \multicolumn{3}{|c|}{$1,25(\mathrm{OH})_{2} \mathrm{D}_{3}[\mu \mathrm{M}]$} \\
\hline C & 0.01 & 0.1 \\
\hline
\end{tabular}
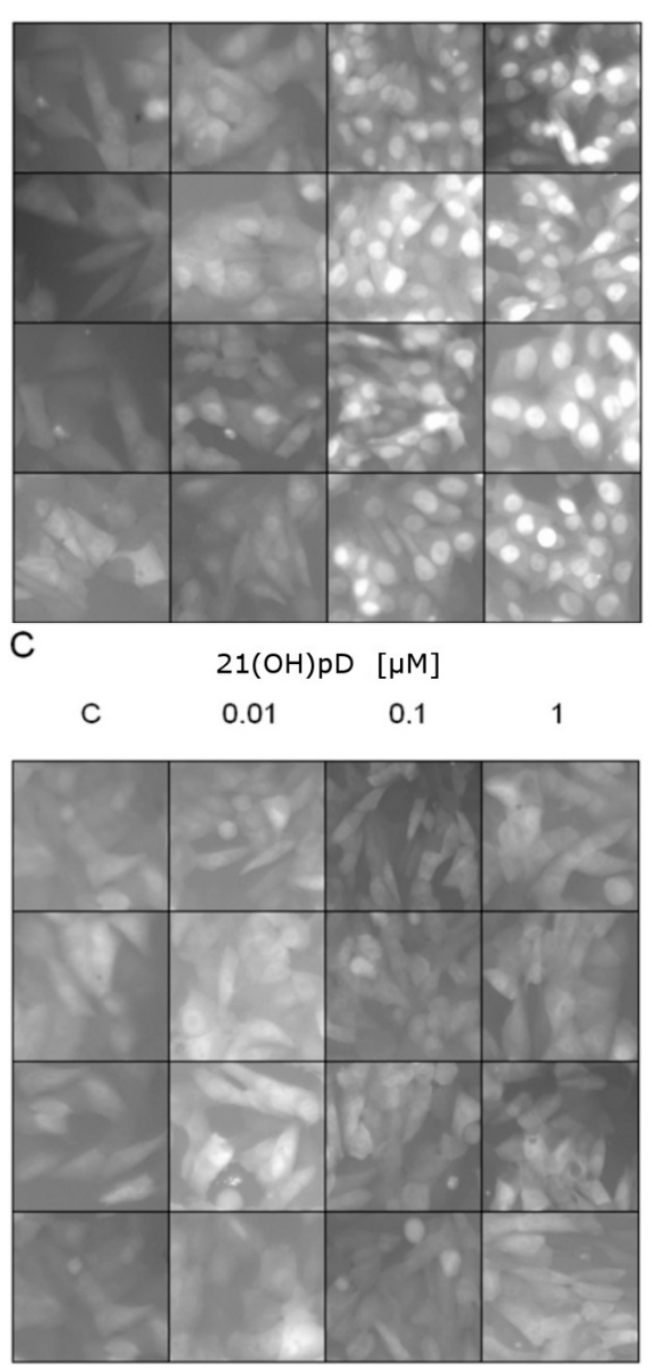

B Calcipotriol $[\mu \mathrm{M}]$

$\begin{array}{llll}C & 0.01 & 0.1 & 1\end{array}$

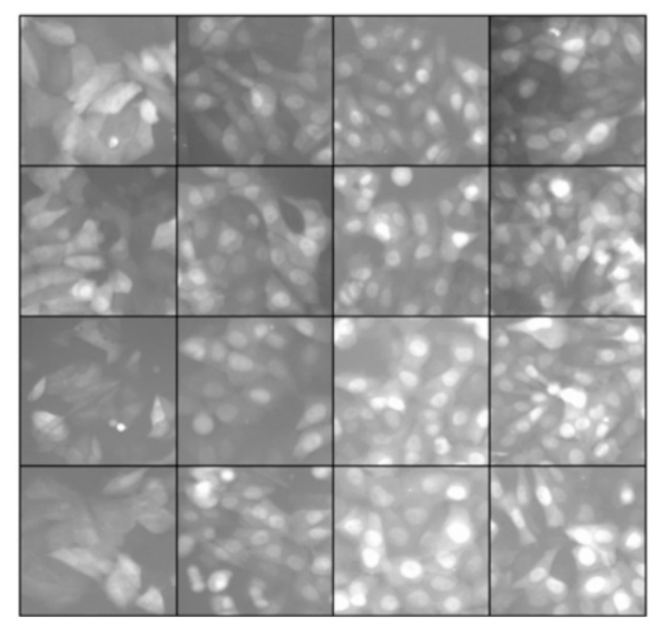

Figure 7. Effects of vitamin D analogs: $(A) 1,25(\mathrm{OH})_{2} \mathrm{D}_{3},(\mathbf{B})$ calcipotriol or $(\mathbf{C}) 21(\mathrm{OH}) \mathrm{pD}_{3}$ at 0 (C-control), 0.01, 0.1 or $1 \mu \mathrm{M}$ concentrations on VDR translocation to the nucleus (green fluorescence shown in a gray scale). Melanoma A375 cells were transduced using pLenti-CMV-VDR-GFP-pgkpuro construct: see Materials and Methods. Vitamin D analogs except 21(OH)pD induce VDR translocation to the nucleus after $1 \mathrm{~h}$ of incubation in a concentration-dependent manner. Each panel shows four random micrographs for each concentration taken by fluorescent microscope under $100 \times$ magnification.

\section{Discussion}

There is growing evidence that vitamin $\mathrm{D}_{3}$ analogs are excellent candidates for melanoma therapy $[40,47,65,71,72]$. This is supported by the strong correlation between an adequate level of $25(\mathrm{OH}) \mathrm{D}_{3}(>30 \mathrm{ng} / \mathrm{mL}$ in the serum) and a decreased incidence or severity of several cancers, 
including melanoma [62,73-77]. However, the use of an active form of vitamin $\mathrm{D}_{3}, 1,25(\mathrm{OH})_{2} \mathrm{D}_{3}$ is limited due to its potential hypercalcemic effects; thus, the development and biological evaluation of new low calcemic vitamin $\mathrm{D}_{3}$ derivatives is highly desirable $[40,55,65,72]$.

Here, we present results showing the different sensitivities of three melanoma cell lines (SK-MEL-188b, A375 and WM98) to vitamin $\mathrm{D}_{3}$ analogs. Recently, we described vitamin $\mathrm{D}_{3}$-resistant clone of SK-MEL1-88 (SK-MEL-188b) [55]. Contrary to parental SK-MEL-188, this clone was insensitive to the treatment with $1,25(\mathrm{OH})_{2} \mathrm{D}_{3}$, or with several analogs of vitamin $\mathrm{D}_{2}$, except of PRI-1731 with the inverse orientation of A ring in comparison to parental $1,25(\mathrm{OH})_{2} \mathrm{D}_{3}$ by the introduction of $(5 \mathrm{Z}, 7 \mathrm{Z})$ modification $[55,78,79]$. This clone does not express the coding region of VDR and of CYP27B1. Therefore, we call it SK-MEL-188VDR ${ }^{-/} \mathrm{CYP}^{-} \mathrm{BB1} 1^{-/}$. Interestingly, a short side-chain analog of vitamin $\mathrm{D}_{3}$ with a pregnacalciferol-type configuration, such as $21(\mathrm{OH}) \mathrm{pD}$, was shown to inhibit the growth of the SK-MEL-188b line. It has to be underlined that this analog, also showed high potency against two other melanoma cell lines in the study (A375 and WM98) and minimal stimulation of CYP24A1. This indicates that the antiproliferative properties of 21-OHpD are independent on its action on the VDR, which is consistent with our previous findings on pregnacalciferol derivatives acting as poor activators of VDR per VDR translocation studies and molecular modeling [69]. One of the possible mechanisms of $21(\mathrm{OH}) \mathrm{pD}$ action could include an activation of non-genomic pathways [25,80], including those linked to the PDIA3 protein $[81,82]$. However, interaction with other nuclear steroid receptors cannot be excluded. In addition, other receptors such as retinoic orphan acid receptors (ROR) $\alpha$ and $\gamma$ can be considered since vitamin D hydroxyderivatives can act as reverse agonists on these receptors [62,83] and related pregnalumisterol derivatives can also act on ROR $\alpha$ and $\mathrm{ROR} \gamma$ [15]. These considerations require future in-depth investigations to define specific receptors for $\mathrm{pD}$ compounds (secosteroids with shortened side-chain).

Two other melanoma lines were responsive to vitamin D (WM98 and A375) and showed relatively high expression levels of $V D R$ transcript. Thus, the studies presented above on three melanoma lines are consistent with reports showing that the expression of $V D R$ is the key factor responsible for the antitumor activities of $1,25(\mathrm{OH})_{2} \mathrm{D}_{3}[18,47,84,85]$. Of note is that its decreased expression correlates with advanced melanoma staging, progression and decreased overall patient survival and disease-free survival time $[45,46]$. Accordingly, VDR polymorphism $[41,42,72]$ and decreased levels of $25(\mathrm{OH}) \mathrm{D}_{3}$ in the serum $[33,86]$ positively correlate with melanoma prevalence and poor prognosis.

Here, we show that sensitivity to tested vitamin $\mathrm{D}_{3}$ hydroxyderivatives with full side-chains depends on $V D R$ expression and its alternative splicing. Interestingly, sensitive melanoma lines (A375, WM98) expressed all three major VDR splicing variants, suggesting that they may play an important but not necessarily identical function in vitamin $D_{3}$ signaling. Further studies are required to elucidate the significance of the expression of $V D R$ splicing variants. Furthermore, the expression of vitamin $\mathrm{D}_{3}$-related genes was altered by vitamin $\mathrm{D}_{3}$ analogs, and the effects on the expression of $V D R, R X R$, PDIA3, CYP2R1 or CYP24A1 were stronger in WM98 melanoma cells in comparison to the A375 line. This phenomenon could explain higher sensitivity of WM98 to $1,25(\mathrm{OH})_{2} \mathrm{D}_{3}$ in comparison to A375 line.

In summary, low calcemic vitamin $\mathrm{D}_{3}$ analogs such as $25(\mathrm{OH}) \mathrm{D}_{3}, 21(\mathrm{OH}) \mathrm{pD}$ or calcipotriol showed similar antiproliferative activity to $1,25(\mathrm{OH})_{2} \mathrm{D}_{3}$ in melanoma cell lines expressing VDR spliced variants. Furthermore, the short side-chain analog $21(\mathrm{OH}) \mathrm{pD}$ was found to be superior among vitamin $\mathrm{D}$ analogs and was the only one, which inhibited the growth of the melanoma subline negative for VDR, indicating a mechanism of action that is VDR-independent.

\section{Materials and Methods}

\subsection{Cell Lines and Vitamin D Analogs}

In our study, we determined the inhibitory effects of vitamin $\mathrm{D}_{3}$ analogs against immortalized human melanoma cell lines SK-MEL-188b, WM98 and A375. SK-MEL-188b cells were cultured 
in F10 medium supplemented with $10 \%$ fetal bovine serum (FBS, Sigma, Poznan, Poland) and $1 \times$ antibiotic-antimycotic solution (Anti-Anti, Sigma). A375 and WM98 cell lines were cultured in Dulbecco's Modified Eagle Medium (DMEM) supplemented with 10\% FBS and 1\% anti-anti. To eliminate the influence of sterols present in fetal bovine serum in the experiments, we used $5 \%$ charcoal-stripped FBS (GE Healthcare Life Sciences, Warsaw, Poland). Vitamin $\mathrm{D}_{3}$ analogs $1,25(\mathrm{OH})_{2} \mathrm{D}_{3}$, $25(\mathrm{OH}) \mathrm{D}_{3}$ and calcipotriol were acquired from the Pharmaceutical Research Institute (Warsaw, Poland), while the new short side analog $21(\mathrm{OH}) \mathrm{pD}$ was synthesized in collaboration with ProChimia Surfaces (Gdynia, Poland) as described previously $[49,50]$. The chemical structures of these secosteroids are presented in Figure 1.

\subsection{SRB Assay}

Melanoma cells were seeded on 96-well plates at a density of 8000 per well in an appropriate medium supplemented with 5\% charcoal-stripped FBS and $1 \times$ anti-anti solution. After $24 \mathrm{~h}$, the medium was replaced with the fresh one containing vehicle and serial dilutions of vitamin $\mathrm{D}_{3}$ analogs at concentrations from $10 \mathrm{pM}$ to $1 \mu \mathrm{M}$. Following incubation for $48 \mathrm{~h}, 100 \mu \mathrm{L}$ of $20 \%$ TCA (trichloroacetic acid) was added and cells were incubated for $1 \mathrm{~h}$ in $4{ }^{\circ} \mathrm{C}$. The medium was discarded and cells were washed 5 times with sterile water. Afterwards, cells were dried and $100 \mu \mathrm{L}$ of SRB ( $0.4 \mathrm{~g}$ sulforhodamin B in $100 \mathrm{~mL} \mathrm{1 \%}$ acetic acid) was added into the plate wells for 15 min incubation at room temperature. Next, cells were washed 5 times with $1 \%$ acetic acid, dried and resolved with $150 \mu \mathrm{L}$ of $10 \mathrm{mM}$ Tris $(\mathrm{pH}=10.5)$ for $10 \mathrm{~min}$ in room temperature. The absorbance was measured spectroscopically at $570 \mathrm{~nm}$ with 96-well plate reader (BioTek, Winooski, VT, USA).

\subsection{Classical PCR and Real-Time PCR Analysis}

SK-MEL-188b, A375 and WM98 melanoma cells were treated with $1,25(\mathrm{OH})_{2} \mathrm{D}_{3}, 25(\mathrm{OH}) \mathrm{D}_{3}$ and calcipotriol (only WM98 line) for $24 \mathrm{~h}$ (Figure 5 and Figure S1) or collected without treatment (Figures 3 and 4). RNA was isolated using a Total RNA Kit (A\&A Biotechnology, Gdynia, Poland). Reverse transcription (500 ng RNA/reaction) was carried out with a RevertAid ${ }^{\mathrm{TM}}$ First Strand cDNA Synthesis Kit (Fermentas, Vilnius, Lithuania). Classic PCR and real-time PCR were performed using 5-fold diluted cDNA and 2× PCR Master Mix (A\&A Biotechnology) or real time $2 \times$ PCR Master Mix SYBR Set A, B (A\&A Biotechnology). The primers to amplify fragments of $A C T B, V D R, R X R$, PDIA3, CYP27A1, CYP2R1, CYP3A4, CYP27B1, CYP24A1, CYP24SV genes were designed with Primer Quest software (Integrated Device Technology, San Jose, CA, USA) (Table S1). The data was collected on a MJ Mini BioRad cycler (BioRad, Hercules, CA, USA) or Termocycler StepOne Real-Time PCR Systems (Life Technologies, Carlsbad, CA, USA). PCR products were visualized using the Mupid-One electrophoresis system (BioRad) and ethidium bromide staining.

\subsection{VDR Translocation}

The melanoma A375 cell line was used to study the VDR receptor translocation to nucleus after vitamin $\mathrm{D}_{3}$ analog treatment. Cells were transduced by pLenti-CMV-VDR-EGFP-pgkpuro plasmid, where VDR and GFP were expressed as a fusion protein in cytoplasmic compartment. Cells were cultured on 12 wells plate $\left(0.5 \times 10^{5}\right.$ cells / well $)$ in DMEM supplemented with $5 \%$ charcoal-stripped FBS and $24 \mathrm{~h}$ later medium was replaced with DMEM containing $1,25(\mathrm{OH})_{2} \mathrm{D}_{3}$, calcipotriol and $21(\mathrm{OH}) \mathrm{pD}$ at $0.01 \mu \mathrm{M}, 0.1 \mu \mathrm{M}$ or $1 \mu \mathrm{M}$ concentrations. After $1 \mathrm{~h}$ of incubation VDR translocation from cytoplasm to nucleus was determined with fluorescent Eclipse TE300 microscope (Nikon, Tokyo, Japan).

\subsection{Statistical Analysis}

SRB viability data was presented using one-way Anova test to compare experimental groups: cells were treated with vitamin $\mathrm{D}_{3}$ analogs with a concentration from $0.01 \mathrm{nM}$ to $1000 \mathrm{nM}$ with control samples (GraphPad Software). The antiproliferative potency of vitamin $\mathrm{D}_{3}$ analogs were compared by the calculation of EC50 for every compound (half maximal effective concentration). 
Real-time PCR data was analyzed with the comparative $\Delta \Delta$-Ct method normalized to the reference gene $A C T B$. As a control, a probe with sterile water was used instead of CDNA. Data are presented as mean \pm SD $(n=4-6)$. Student's $t$-test (for two groups) or one-way ANOVA with appropriate post-hoc test (for more than two groups) were used to analyze data using Excel (Microsoft) or Prism 7.00 (GraphPad Software), respectively. Statistically significant differences are denoted with asterisks: $p<0.05\left(^{*} p<0.05 ;{ }^{* *} p<0.01 ;{ }^{* * *} p<0.0001\right)$.

Supplementary Materials: Supplementary materials can be found at http:/ / www.mdpi.com/1422-0067/19/9/ 2583/s1.

Author Contributions: T.W. and A.P. and J.W. performed the main experiments, took part in data analysis and preparation of the manuscript. M.A.Z. and A.T.S. designed experiments; M.A.Z., T.W., J.W. and A.T.S. analyzed data and prepared final version of the manuscript.

Acknowledgments: The study was supported by a grant of the Polish Ministry of Science and Higher Education, Project No. N405 623238 and National Science Center OPUS Program under contract 2017/25/B/NZ3/00431 to MAZ; and NIH grants 1 R01AR073004-01A1. 1 RO1 AR071189-01A1 and R21AR066505 to ATS. Authors would like to thank Adam Figarski, MD, for help in experiment with VDR translocation.

Conflicts of Interest: The authors declare no conflict of interest.

\title{
Abbreviations
}

\author{
$1 \alpha, 25(\mathrm{OH})_{2} \mathrm{D}_{3} \quad 1 \alpha, 25$-dihydroxyvitamin $\mathrm{D}_{3}$ (calcitriol) \\ 21( $\mathrm{OH}) \mathrm{pD} \quad$ 21-hydroxypregnacalciferol \\ $25(\mathrm{OH}) \mathrm{D}_{3} \quad$ 25-hydroxyvitamin $\mathrm{D}_{3}$ (calcifediol) \\ 7-DHC 7-dehydrocholesterol (provitamin $\mathrm{D}_{3}$, cholesta-5,7-dien-3 $\beta$-ol) \\ 7-DHP 7-dehydropregnenolone \\ MARRS receptor Membrane-Associated Rapid Response to Steroid binding protein (other names: ERp57, \\ GRp58, Pdia3) \\ PDIA3 Protein disulfide-isomerase A3 \\ ROS reactive oxygen species \\ $\mathrm{UVA} / \mathrm{B} \quad$ ultraviolet radiation A and B \\ VDR vitamin D receptor \\ VDRE vitamin D response elements
}

\section{References}

1. Holick, M.F. Vitamin D: Evolutionary, physiological and health perspectives. Curr. Drug Targets 2011, 12, 4-18. [CrossRef] [PubMed]

2. Bikle, D.D. Vitamin D and the skin: Physiology and pathophysiology. Rev. Endocr. Metab. Dis. 2012, 13, 3-19. [CrossRef] [PubMed]

3. Wierzbicka, J.; Piotrowska, A.; Żmijewski, M.A. The renaissance of vitamin D. Acta Biochim. Pol. 2014, 61, 679-686. [PubMed]

4. Holick, M.F. Sunlight, UV-radiation, vitamin D and skin cancer: How much sunlight do we need? Adv. Exp. Med. Biol. 2014, 810, 1-16. [PubMed]

5. Wacker, M.; Holick, M.F. Sunlight and vitamin D: A global perspective for health. Dermatoendocrinol 2013, 5, 51-108. [CrossRef] [PubMed]

6. Tangpricha, V.; Flanagan, J.N.; Whitlatch, L.W.; Tseng, C.C.; Chen, T.C.; Holt, P.R.; Lipkin, M.S.; Holick, M.F. 25-hydroxyvitamin D-1 $\alpha$-hydroxylase in normal and malignant colon tissue. Lancet 2001, 357, 1673-1674. [CrossRef]

7. Radermacher, J.; Diesel, B.; Seifert, M.; Tilgen, W.; Reichrath, J.; Fischer, U.; Meese, E. Expression analysis of CYP27B1 in tumor biopsies and cell cultures. Anticancer Res. 2006, 26, 2683-2686. [PubMed]

8. Yu, O.B.; Arnold, L.A. Calcitroic acid-a review. ACS Chem. Biol. 2016, 11, 2665-2672. [CrossRef] [PubMed]

9. Ren, S.; Nguyen, L.; Wu, S.; Encinas, C.; Adams, J.S.; Hewison, M. Alternative splicing of vitamin D-24-hydroxylase: A novel mechanism for the regulation of extrarenal 1,25-dihydroxyvitamin D synthesis. J. Biol. Chem. 2005, 280, 20604-20611. [CrossRef] [PubMed] 
10. Slominski, A.T.; Zmijewski, M.A.; Semak, I.; Sweatman, T.; Janjetovic, Z.; Li, W.; Zjawiony, J.K.; Tuckey, R.C. Sequential metabolism of 7-dehydrocholesterol to steroidal 5,7-dienes in adrenal glands and its biological implication in the skin. PLoS ONE 2009, 4, e4309. [CrossRef] [PubMed]

11. Slominski, A.T.; Li, W.; Kim, T.K.; Semak, I.; Wang, J.; Zjawiony, J.K.; Tuckey, R.C. Novel activities of cyp11a1 and their potential physiological significance. J. Steroid Biochem. 2015, 151, 25-37. [CrossRef] [PubMed]

12. Slominski, A.T.; Kim, T.K.; Li, W.; Postlethwaite, A.; Tieu, E.W.; Tang, E.K.; Tuckey, R.C. Detection of novel cyp11a1-derived secosteroids in the human epidermis and serum and pig adrenal gland. Sci. Rep. 2015, 5, 14875. [CrossRef] [PubMed]

13. Slominski, A.T.; Kim, T.K.; Shehabi, H.Z.; Semak, I.; Tang, E.K.; Nguyen, M.N.; Benson, H.A.; Korik, E.; Janjetovic, Z.; Chen, J.; et al. In vivo evidence for a novel pathway of vitamin $\mathrm{D}_{3}$ metabolism initiated by P450scc and modified by CYP27B1. FASEB J. 2012, 26, 3901-3915. [CrossRef] [PubMed]

14. Slominski, A.T.; Kim, T.K.; Chen, J.; Nguyen, M.N.; Li, W.; Yates, C.R.; Sweatman, T.; Janjetovic, Z.; Tuckey, R.C. Cytochrome P450scc-dependent metabolism of 7-dehydrocholesterol in placenta and epidermal keratinocytes. Int. J. Biochem. Cell Biol. 2012, 44, 2003-2018. [CrossRef] [PubMed]

15. Slominski, A.T.; Kim, T.K.; Hobrath, J.V.; Janjetovic, Z.; Oak, A.S.W.; Postlethwaite, A.; Lin, Z.; Li, W.; Takeda, Y.; Jetten, A.M.; et al. Characterization of a new pathway that activates lumisterol in vivo to biologically active hydroxylumisterols. Sci. Rep. 2017, 7, 11434. [CrossRef] [PubMed]

16. Cavalier, E.; Delanaye, P.; Chapelle, J.P.; Souberbielle, J.C. Vitamin D: Current status and perspectives. Clin. Chem. Lab. Med. 2009, 47, 120-127. [CrossRef] [PubMed]

17. Campbell, M.J. Vitamin D and the RNA transcriptome: More than mRNA regulation. Front. Physiol. 2014, 5, 181. [CrossRef] [PubMed]

18. Long, M.D.; Sucheston-Campbell, L.E.; Campbell, M.J. Vitamin D receptor and RXR in the post-genomic era. J. Cell. Physiol. 2015, 230, 758-766. [CrossRef] [PubMed]

19. Liaw, C.W.; Grigoriadis, D.E.; Lovenberg, T.W.; De Souza, E.B.; Maki, R.A. Localization of ligand-binding domains of human corticotropin-releasing factor receptor: A chimeric receptor approach. Mol. Endocrinol. 1997, 11, 980-985. [CrossRef] [PubMed]

20. Kerry, D.M.; Dwivedi, P.P.; Hahn, C.N.; Morris, H.A.; Omdahl, J.L.; May, B.K. Transcriptional synergism between vitamin D-responsive elements in the rat 25-hydroxyvitamin $\mathrm{D}_{3}$ 24-hydroxylase (CYP24) promoter. J. Biol. Chem. 1996, 271, 29715-29721. [CrossRef] [PubMed]

21. Wang, T.T.; Tavera-Mendoza, L.E.; Laperriere, D.; Libby, E.; MacLeod, N.B.; Nagai, Y.; Bourdeau, V.; Konstorum, A.; Lallemant, B.; Zhang, R.; et al. Large-scale in silico and microarray-based identification of direct 1,25-dihydroxyvitamin $\mathrm{D}_{3}$ target genes. Mol. Endocrinol. 2005, 19, 2685-2695. [CrossRef] [PubMed]

22. Reichrath, J. Will analogs of 1,25-dihydroxyvitamin $\mathrm{D}_{3}$ (calcitriol) open a new era in cancer therapy? Onkologie 2001, 24, 128-133. [PubMed]

23. Nemere, I.; Garbi, N.; Hämmerling, G.J.; Khanal, R.C. Intestinal cell calcium uptake and the targeted knockout of the $1,25 \mathrm{D}_{3}$-MARRS (membrane-associated, rapid response steroid-binding) receptor/PDIA3/Erp57. J. Biol. Chem. 2010, 285, 31859-31866. [CrossRef] [PubMed]

24. Cui, X.; Gooch, H.; Petty, A.; McGrath, J.J.; Eyles, D. Vitamin D and the brain: Genomic and non-genomic actions. Mol. Cell. Endocrinol. 2017, 453, 131-143. [CrossRef] [PubMed]

25. Hii, C.S.; Ferrante, A. The non-genomic actions of vitamin D. Nutrients 2016, 8, 135. [CrossRef] [PubMed]

26. Huhtakangas, J.A.; Olivera, C.J.; Bishop, J.E.; Zanello, L.P.; Norman, A.W. The vitamin D receptor is present in caveolae-enriched plasma membranes and binds $1 \alpha, 25(\mathrm{OH}) 2$-vitamin $\mathrm{D}_{3}$ in vivo and in vitro. Mol. Endocrinol. 2004, 18, 2660-2671. [CrossRef] [PubMed]

27. Zhao, G.; Simpson, R.U. Membrane localization, caveolin-3 association and rapid actions of vitamin D receptor in cardiac myocytes. Steroids 2010, 75, 555-559. [CrossRef] [PubMed]

28. Nemere, I.; Safford, S.E.; Rohe, B.; DeSouza, M.M.; Farach-Carson, M.C. Identification and characterization of $1,25 \mathrm{D}_{3}$-membrane-associated rapid response, steroid $\left(1,25 \mathrm{D}_{3}\right.$-MARRS) binding protein. J. Steroid Biochem. 2004, 89-90, 281-285. [CrossRef] [PubMed]

29. Strouse, J.J.; Fears, T.R.; Tucker, M.A.; Wayne, A.S. Pediatric melanoma: Risk factor and survival analysis of the surveillance, epidemiology and end results database. J. Clin. Oncol. 2005, 23, 4735-4741. [CrossRef] [PubMed] 
30. Barroso, E.; Fernandez, L.P.; Milne, R.L.; Pita, G.; Sendagorta, E.; Floristan, U.; Feito, M.; Aviles, J.A.; Martin-Gonzalez, M.; Arias, J.I.; et al. Genetic analysis of the vitamin D receptor gene in two epithelial cancers: Melanoma and breast cancer case-control studies. BMC Cancer 2008, 8, 385. [CrossRef] [PubMed]

31. Yan, S.F.; Ramasamy, R.; Naka, Y.; Schmidt, A.M. Glycation, inflammation, and rage: A scaffold for the macrovascular complications of diabetes and beyond. Circ. Res. 2003, 93, 1159-1169. [CrossRef] [PubMed]

32. Arnold, M.; de Vries, E.; Whiteman, D.C.; Jemal, A.; Bray, F.; Parkin, D.M.; Soerjomataram, I. Global burden of cutaneous melanoma attributable to ultraviolet radiation in 2012. Int. J. Cancer 2018, 143, 1305-1314. [CrossRef] [PubMed]

33. Reichrath, J.; Reichrath, S. Sunlight, vitamin D and malignant melanoma: An update. Adv. Exp. Med. Biol. 2014, 810, 390-405. [PubMed]

34. Lo, J.A.; Fisher, D.E. The melanoma revolution: From UV carcinogenesis to a new era in therapeutics. Science 2014, 346, 945-949. [CrossRef] [PubMed]

35. Mansur, C.P.; Gordon, P.R.; Ray, S.; Holick, M.F.; Gilchrest, B.A. Vitamin D, its precursors, and metabolites do not affect melanization of cultured human melanocytes. J. Investing. Dermatol. 1988, 91, 16-21. [CrossRef]

36. Reichrath, J. Skin cancer prevention and UV-protection: How to avoid vitamin D-deficiency? Brit. J. Dermatol. 2009, 161, 54-60. [CrossRef] [PubMed]

37. Wagner, C.L.; McNeil, R.B.; Johnson, D.D.; Hulsey, T.C.; Ebeling, M.; Robinson, C.; Hamilton, S.A.; Hollis, B.W. Health characteristics and outcomes of two randomized vitamin D supplementation trials during pregnancy: A combined analysis. J. Steroid Biochem. 2013, 136, 313-320. [CrossRef] [PubMed]

38. Pelczynska, M.; Switalska, M.; Maciejewska, M.; Jaroszewicz, I.; Kutner, A.; Opolski, A. Antiproliferative activity of vitamin D compounds in combination with cytostatics. Anticancer Res. 2006, 26, 2701-2705. [PubMed]

39. Slominski, A.T.; Janjetovic, Z.; Kim, T.K.; Wright, A.C.; Grese, L.N.; Riney, S.J.; Nguyen, M.N.; Tuckey, R.C. Novel vitamin D hydroxyderivatives inhibit melanoma growth and show differential effects on normal melanocytes. Anticancer Res. 2012, 32, 3733-3742. [PubMed]

40. Slominski, A.T.; Brożyna, A.A.; Skobowiat, C.; Zmijewski, M.A.; Kim, T.K.; Janjetovic, Z.; Oak, A.S.; Jozwicki, W.; Jetten, A.M.; Mason, R.S.; et al. On the role of classical and novel forms of vitamin D in melanoma progression and management. J. Steroid Biochem. 2018, 177, 159-170. [CrossRef] [PubMed]

41. Cauci, S.; Maione, V.; Buligan, C.; Linussio, M.; Serraino, D.; Stinco, G. Bsmi (rs1544410) and foki (rs2228570) vitamin D receptor polymorphisms, smoking, and body mass index as risk factors of cutaneous malignant melanoma in northeast italy. Cancer Biol. Med. 2017, 14, 302-318. [CrossRef] [PubMed]

42. La Marra, F.; Stinco, G.; Buligan, C.; Chiriacò, G.; Serraino, D.; Di Loreto, C.; Cauci, S. Immunohistochemical evaluation of vitamin D receptor (VDR) expression in cutaneous melanoma tissues and four VDR gene polymorphisms. Cancer Biol. Med. 2017, 14, 162-175. [PubMed]

43. Orlow, I.; Reiner, A.S.; Thomas, N.E.; Roy, P.; Kanetsky, P.A.; Luo, L.; Paine, S.; Armstrong, B.K.; Kricker, A.; Marrett, L.D.; et al. Vitamin D receptor polymorphisms and survival in patients with cutaneous melanoma: A population-based study. Carcinogenesis 2016, 37, 30-38. [CrossRef] [PubMed]

44. Brożyna, A.A.; Jochymski, C.; Janjetovic, Z.; Jóźwicki, W.; Tuckey, R.C.; Slominski, A.T. CYP24A1 expression inversely correlates with melanoma progression: Clinic-pathological studies. Int. J. Mol. Sci. 2014, 15, 19000-19017. [CrossRef] [PubMed]

45. Brożyna, A.A.; Jozwicki, W.; Janjetovic, Z.; Slominski, A.T. Expression of vitamin D receptor decreases during progression of pigmented skin lesions. Hum. Pathol. 2011, 42, 618-631. [CrossRef] [PubMed]

46. Brożyna, A.A.; Jóźwicki, W.; Slominski, A.T. Decreased VDR expression in cutaneous melanomas as marker of tumor progression: New data and analyses. Anticancer Res. 2014, 34, 2735-2743. [PubMed]

47. Slominski, A.T.; Brożyna, A.A.; Zmijewski, M.A.; Jóźwicki, W.; Jetten, A.M.; Mason, R.S.; Tuckey, R.C.; Elmets, C.A. Vitamin D signaling and melanoma: Role of vitamin D and its receptors in melanoma progression and management. Lab. Invest. 2017, 97, 706-724. [CrossRef] [PubMed]

48. Brożyna, A.A.; Jóźwicki, W.; Janjetovic, Z.; Slominski, A.T. Expression of the vitamin D-activating enzyme $1 \alpha$-hydroxylase (CYP27B1) decreases during melanoma progression. Hum. Pathol. 2013, 44, 374-387. [CrossRef] [PubMed]

49. Timerman, D.; McEnery-Stonelake, M.; Joyce, C.J.; Nambudiri, V.E.; Hodi, F.S.; Claus, E.B.; Ibrahim, N.; Lin, J.Y. Vitamin D deficiency is associated with a worse prognosis in metastatic melanoma. Oncotarget 2017, 8, 6873-6882. [CrossRef] [PubMed] 
50. Grant, W.B. Roles of solar UVB and vitamin D in reducing cancer risk and increasing survival. Anticancer Res. 2016, 36, 1357-1370. [PubMed]

51. Płudowski, P.; Karczmarewicz, E.; Bayer, M.; Carter, G.; Chlebna-Sokół, D.; Czech-Kowalska, J.; Dębski, R.; Decsi, T.; Dobrzańska, A.; Franek, E.; et al. Practical guidelines for the supplementation of vitamin D and the treatment of deficits in central europe-recommended vitamin D intakes in the general population and groups at risk of vitamin D deficiency. Endokrynol. Pol. 2013, 64, 319-327. [CrossRef] [PubMed]

52. Wierzbicka, J.M.; Binek, A.; Ahrends, T.; Nowacka, J.D.; Szydłowska, A.; Turczyk, Ł.; Wąsiewicz, T.; Wierzbicki, P.M.; Sądej, R.; Tuckey, R.C.; et al. Differential antitumor effects of vitamin d analogues on colorectal carcinoma in culture. Int. J. Oncol. 2015, 47, 1084-1096. [CrossRef] [PubMed]

53. Nag, K.; Sultana, N.; Kato, A.; Hirose, S. Headless splice variant acting as dominant negative calcitonin receptor. Biochem. Biophys. Res. Commun. 2007, 362, 1037-1043. [CrossRef] [PubMed]

54. Giardino, W.J.; Mark, G.P.; Stenzel-Poore, M.P.; Ryabinin, A.E. Dissociation of corticotropin-releasing factor receptor subtype involvement in sensitivity to locomotor effects of methamphetamine and cocaine. Psychopharmacology 2012, 219, 1055-1063. [CrossRef] [PubMed]

55. Piotrowska, A.; Wierzbicka, J.; Nadkarni, S.; Brown, G.; Kutner, A.; Żmijewski, M.A. Antiproliferative activity of double point modified analogs of 1,25-dihydroxyvitamin $\mathrm{D}_{2}$ against human malignant melanoma cell lines. Int. J. Mol. Sci. 2016, 17, 76. [CrossRef] [PubMed]

56. Wasiewicz, T.; Szyszka, P.; Cichorek, M.; Janjetovic, Z.; Tuckey, R.C.; Slominski, A.T.; Zmijewski, M.A. Antitumor effects of vitamin D analogs on hamster and mouse melanoma cell lines in relation to melanin pigmentation. Int. J. Mol. Sci. 2015, 16, 6645-6667. [CrossRef] [PubMed]

57. Zmijewski, M.A.; Li, W.; Chen, J.; Kim, T.K.; Zjawiony, J.K.; Sweatman, T.W.; Miller, D.D.; Slominski, A.T. Synthesis and photochemical transformation of 3 $\alpha 21$-dihydroxypregna-5,7-dien-20-one to novel secosteroids that show anti-melanoma activity. Steroids 2011, 76, 193-203. [CrossRef] [PubMed]

58. Skobowiat, C.; Oak, A.S.; Kim, T.K.; Yang, C.H.; Pfeffer, L.M.; Tuckey, R.C.; Slominski, A.T. Noncalcemic 20-hydroxyvitamin $\mathrm{D}_{3}$ inhibits human melanoma growth in in vitro and in vivo models. Oncotarget 2017, 8 , 9823-9834. [CrossRef] [PubMed]

59. Slominski, A.; Kim, T.K.; Zmijewski, M.A.; Janjetovic, Z.; Li, W.; Chen, J.; Kusniatsova, E.I.; Semak, I.; Postlethwaite, A.; Miller, D.D.; et al. Novel vitamin D photoproducts and their precursors in the skin. Dermatoendocrinol 2013, 5, 7-19. [CrossRef] [PubMed]

60. Zmijewski, M.A.; Fisches, T.W.; Slominski, A.T. Melatonin regulates expression and activity of androgen related genes in human skin cells. J. Invest. Dermatol. 2008, 128, 893.

61. Plum, L.A.; Prahl, J.M.; Ma, X.; Sicinski, R.R.; Gowlugari, S.; Clagett-Dame, M.; DeLuca, H.F. Biologically active noncalcemic analogs of $1 \alpha, 25$-dihydroxyvitamin $\mathrm{D}$ with an abbreviated side chain containing no hydroxyl. Proc. Natl. Acad. Sci. USA 2004, 101, 6900-6904. [CrossRef] [PubMed]

62. Slominski, A.T.; Kim, T.K.; Hobrath, J.V.; Oak, A.S.W.; Tang, E.K.Y.; Tieu, E.W.; Li, W.; Tuckey, R.C.; Jetten, A.M. Endogenously produced nonclassical vitamin D hydroxy-metabolites act as "Biased" Agonists on VDR and inverse agonists on roralpha and rorgamma. J. Steroid Biochem. 2017, 173, 42-56. [CrossRef] [PubMed]

63. Wang, J.; Slominski, A.; Tuckey, R.C.; Janjetovic, Z.; Kulkarni, A.; Chen, J.; Postlethwaite, A.E.; Miller, D.; Li, W. 20-hydroxyvitamin $\mathrm{D}_{3}$ inhibits proliferation of cancer cells with high efficacy while being non-toxic. Anticancer Res. 2012, 32, 739-746. [PubMed]

64. Duffy, M.J.; Murray, A.; Synnott, N.C.; O'Donovan, N.; Crown, J. Vitamin D analogues: Potential use in cancer treatment. Crit. Rev. Oncol. Hematol. 2017, 112, 190-197. [CrossRef] [PubMed]

65. Szyszka, P.; Zmijewski, M.A.; Slominski, A.T. New vitamin D analogs as potential therapeutics in melanoma. Expert Rev. Anticancer Ther. 2012, 12, 585-599. [CrossRef] [PubMed]

66. Reichrath, J.; Zouboulis, C.C.; Vogt, T.; Holick, M.F. Targeting the vitamin D endocrine system (VDES) for the management of inflammatory and malignant skin diseases: An historical view and outlook. Rev. Endocr. Metab. Disord. 2016, 17, 405-417. [CrossRef] [PubMed]

67. Zmijewski, M.A.; Li, W.; Zjawiony, J.K.; Sweatman, T.W.; Chen, J.; Miller, D.D.; Slominski, A.T. Photo-conversion of two epimers (20R and 20S) of pregna-5,7-diene-3 $\beta, 17 \alpha, 20$-triol and their bioactivity in melanoma cells. Steroids 2009, 74, 218-228. [CrossRef] [PubMed]

68. Janjetovic, Z.; Brozyna, A.A.; Tuckey, R.C.; Kim, T.K.; Nguyen, M.N.; Jozwicki, W.; Pfeffer, S.R.; Pfeffer, L.M.; Slominski, A.T. High basal NF-kB activity in nonpigmented melanoma cells is associated with an enhanced sensitivity to vitamin $\mathrm{D}_{3}$ derivatives. Brit. J. Cancer. 2011, 105, 1874-1884. [CrossRef] [PubMed] 
69. Kim, T.K.; Wang, J.; Janjetovic, Z.; Chen, J.; Tuckey, R.C.; Nguyen, M.N.; Tang, E.K.; Miller, D.; Li, W.; Slominski, A.T. Correlation between secosteroid-induced vitamin D receptor activity in melanoma cells and computer-modeled receptor binding strength. Mol. Cell. Endocrinol. 2012, 361, 143-152. [CrossRef] [PubMed]

70. Slominski, A.T.; Kim, T.K.; Janjetovic, Z.; Tuckey, R.C.; Bieniek, R.; Yue, J.; Li, W.; Chen, J.; Nguyen, M.N.; Tang, E.K.; et al. 20-hydroxyvitamin $\mathrm{D}_{2}$ is a noncalcemic analog of vitamin $\mathrm{D}$ with potent antiproliferative and prodifferentiation activities in normal and malignant cells. Am. J. Physiol. Cell Physiol. 2011, 300, C526-C541. [CrossRef] [PubMed]

71. Carlberg, C.; Seuter, S. A genomic perspective on vitamin D signaling. Anticancer Res. 2009, $29,3485-3493$. [PubMed]

72. Piotrowska, A.; Wierzbicka, J.; Żmijewski, M.A. Vitamin D in the skin physiology and pathology. Acta. Biochim. Pol. 2016, 63, 17-29. [CrossRef] [PubMed]

73. Hansen, C.M.; Madsen, M.W.; Arensbak, B.; Skak-Nielsen, T.; Latini, S.; Binderup, L. Down-regulation of laminin-binding integrins by $1 \alpha, 25$-dihydroxyvitamin $\mathrm{D}_{3}$ in human melanoma cells in vitro. Cell Adhes. Commun. 1998, 5, 109-120. [CrossRef] [PubMed]

74. Evans, S.R.; Houghton, A.M.; Schumaker, L.; Brenner, R.V.; Buras, R.R.; Davoodi, F.; Nauta, R.J.; Shabahang, M. Vitamin D receptor and growth inhibition by 1,25-dihydroxyvitamin $\mathrm{D}_{3}$ in human malignant melanoma cell lines. J. Surg. Res. 1996, 61, 127-133. [CrossRef] [PubMed]

75. Essa, S.; Denzer, N.; Mahlknecht, U.; Klein, R.; Collnot, E.M.; Schäfer, U.; Tilgen, W.; Reichrath, J. VDR microrna expression and epigenetic silencing of vitamin D signaling in melanoma cells. J. Steroid Biochem. 2010, 121, 110-113. [CrossRef] [PubMed]

76. Krishnan, A.V.; Peehl, D.M.; Feldman, D. The role of vitamin D in prostate cancer. Recent Results Cancer Res. 2003, 164, 205-221. [PubMed]

77. Seifert, M.; Rech, M.; Meineke, V.; Tilgen, W.; Reichrath, J. Differential biological effects of 1,25-dihydroxyvitamin $\mathrm{D}_{3}$ on melanoma cell lines in vitro. J. Steroid Biochem. 2004, 89-90, 375-379. [CrossRef] [PubMed]

78. Corcoran, A.; Nadkarni, S.; Yasuda, K.; Sakaki, T.; Brown, G.; Kutner, A.; Marcinkowska, E. Biological evaluation of double point modified analogues of 1,25-dihydroxyvitamin $\mathrm{D}_{2}$ as potential anti-leukemic agents. Int. J. Mol. Sci. 2016, 17, 91. [CrossRef] [PubMed]

79. Nadkarni, S.; Chodyński, M.; Krajewski, K.; Cmoch, P.; Marcinkowska, E.; Brown, G.; Kutner, A. Convergent synthesis of double point modified analogs of $1 \alpha, 25$-dihydroxyvitamin $\mathrm{D}_{2}$ for biological evaluation. J. Steroid Biochem. 2016, 164, 45-49. [CrossRef] [PubMed]

80. Trochoutsou, A.I.; Kloukina, V.; Samitas, K.; Xanthou, G. Vitamin-D in the immune system: Genomic and non-genomic actions. Mini Rev. Med. Chem. 2015, 15, 953-963. [CrossRef] [PubMed]

81. Doroudi, M.; Plaisance, M.C.; Boyan, B.D.; Schwartz, Z. Membrane actions of $1 \alpha, 25(\mathrm{OH})_{2} \mathrm{D}_{3}$ are mediated by $\mathrm{Ca}^{2+} /$ calmodulin-dependent protein kinase II in bone and cartilage cells. J. Steroid Biochem. 2015, 145, 65-74. [CrossRef] [PubMed]

82. Chen, J.; Doroudi, M.; Cheung, J.; Grozier, A.L.; Schwartz, Z.; Boyan, B.D. Plasma membrane PDIA3 and VDR interact to elicit rapid responses to $1 \alpha, 25 \mathrm{OH}_{2} \mathrm{D}_{3}$. Cell. Signal. 2013, 25, 2362-2373. [CrossRef] [PubMed]

83. Slominski, A.T.; Kim, T.K.; Takeda, Y.; Janjetovic, Z.; Brozyna, A.A.; Skobowiat, C.; Wang, J.; Postlethwaite, A.; Li, W.; Tuckey, R.C.; et al. ROR $\alpha$ and ROR $\gamma$ are expressed in human skin and serve as receptors for endogenously produced noncalcemic 20-hydroxy-and 20,23-dihydroxyvitamin D. FASEB J. 2014, 28, 2775-2789. [CrossRef] [PubMed]

84. Bikle, D.D.; Jiang, Y.; Nguyen, T.; Oda, Y.; Tu, C.L. Disruption of vitamin D and calcium signaling in keratinocytes predisposes to skin cancer. Front Physiol. 2016, 7, 296. [CrossRef] [PubMed]

85. Slominski, A.T.; Zmijewski, M.A.; Plonka, P.M.; Szaflarski, J.P.; Paus, R. How UV light touches the brain and endocrine system through skin, and why. Endocrinology 2018, 159, 1992-2007. [CrossRef] [PubMed]

86. Wyatt, C.; Lucas, R.M.; Hurst, C.; Kimlin, M.G. Vitamin D deficiency at melanoma diagnosis is associated with higher breslow thickness. PLoS ONE 2015, 10, e0126394. [CrossRef] [PubMed]

(C) 2018 by the authors. Licensee MDPI, Basel, Switzerland. This article is an open access article distributed under the terms and conditions of the Creative Commons Attribution (CC BY) license (http:/ / creativecommons.org/licenses/by/4.0/). 